\title{
Numerical Experiments of Conditional Symmetric Baroclinic Instability as a

\author{
Possible Cause for Frontal Rainband Formation
} \\ Part II. Effects of Water Vapor Supply
}

\author{
By Sadamu Saitoh and Hiroshi Tanaka \\ Water Research Institute, Nagoya University, Chikusa-ku, Nagoya 464, Japan \\ (Manuscript received 12 September 1987, in revised form 10 December 1987)
}

\begin{abstract}
The main purpose of this paper is to study numerically how the low level water vapor supply modifies the circulation of conditional symmetric baroclinic instability (CSBI), and how the convective clouds are induced and controlled by CSBI circulation. The numerical model is basically the same as that used in Part I by the same authors, whereas the water vapor is supplied from the surface. Three cases of numerical experiment are considered: no water vapor supply, a small water vapor supply, and a large water vapor supply. Developments of clouds, rainfall and stratification are the main features inspected in the three cases.

When the water vapor supply is moderate, a slantwise cloud is also developed due to the CSBI circulation, as in the case of no water vapor supply. However, nodal convective cells appear embedded in the slantwise cloud. A number of narrow, strong precipitation areas are embedded in the weak and wide-spread precipitation area and are associated with these nodal cells. Convective cells above the slantwise cloud (generating cells) are also developed in the mid-troposphere. When the water vapor supply increases, strong convective clouds rapidly grow at the convergence zone of CSBI circulation and at the slantwise convective unstable layer. The horizontal extension of the rainfall area becomes narrow but the rainfall intensity is greatly enhanced.

One of the most important features of the CSBI circulation in rainband formation is to induce the slantwise convective unstable layer, which is appreciably enhanced as the rate of water vapor supply increases. At the same time, an increase of water vapor supply tends to activate cumulus clouds through the combined effect of low level convective unstable layer due to water vapor supply and flow convergence due to CSBI circulation.
\end{abstract}

\section{Introduction}

Areas of precipitations are frequently organized in bands parallel to the fronts associated with extratropical cyclones. The mechanism of frontal rainband formation is one of the most exciting research topics in meteorology. Conditional symmetric baroclinic instability (CSBI), which was proposed by Bennets and Hoskins (1979) and Emanuel (1979) is principally responsible for producing mesoscale slantwise stratiform clouds and associated rain-

(C) 1988, Meteorological Society of Japan bands with weak rainfall, at most $10 \mathrm{~mm} \mathrm{~h}^{-1}$ (Emanuel, 1983; Bennets and Ryder, 1984; Seltzer et al., 1985; Wolfsberg et al., 1986). Saitoh and Tanaka (1987, hereafter called Part I) succeeded in demonstrating, by a sophisticated numerical model, that many typical observational features of warm-frontal or wide coldfrontal rainbands associated with extratropical cyclones could be rationally explained by CSBI.

However, CSBI treated by Part $I$ is rather simple in the sense that no water vapor supply is assumed except for an initial condition of water vapor distribution. Zonally averaged evaporation 
from the sea surface in mid-latitude is about 2 to $3 \mathrm{~mm}$ day $^{-1}$. In subtropical latitudes, evaporation rates reach $6 \mathrm{~mm}$ day $^{-1}$ (Akiyama, 1973). Water vapor supply due to evaporation cannot be ignored if we wish to better understand the realistic role of CSBI in forming frontal rainbands.

Various types of rainband are observed associated with extratropical cyclones. Shallow convections at the mid-troposphere (generating cells) play an important role in the formation of warm-frontal and wide cold-frontal rainbands. On the other hand, deep convections prevail in narrow cold-frontal and warm sector rainbands (Hobbs, 1978; Houze and Hobbs, 1982).

Rainbands are also observed in the Baiu frontal zone, which have high precipitation intensities and are associated with the meso- $\alpha$ scale cyclones which develop in the Baiu frontal zone (Akiyama, 1973, 1975, 1978, 1979; Matsumoto et al., 1971; Ninomiya and Akiyama, 1972; Ninomiya and Yamasaki, 1979; Ninomiya et al., 1981; Yoshizumi, 1977; Ogura et al., 1985).

It can be said that mesoscale rainbands are formed by a parent cell which produces new cells around it. The self-production mechanism is valid in the tropics where baroclinicity is rarely observed (Nakajima and Matsuno, 1988). However, this does not always play a major role in the mid-latitudinal baroclinic zone, if any, since several kinds of disturbance associated with baroclinicity tightly control the behavior of convections.

The main purpose of the present paper is to study how the cloud and precipitation associated with CSBI circulation are modified as the water vapor supply increases. We use the same numerical model and initial condition as in Part I except that here we supply water vapor from the bottom. Several experiments are designed with different rates of water vapor supply.

In Section 2 we present the numerical model assuming zonal symmetry. Numerical solutions are discussed in Section 3 for several different rates of water vapor supply. Finally, conclusions are given in Section 4.

\section{Numerical model}

We use the same numerical model and initial conditions as that described in Part I, except for adding a forcing term in the equation for water vapor. Below, we summarize the numerical model used in Part $I$ and then present the method of water vapor supply.

\section{a. Outline of the model}

Basic equations are compressible, nonhydrostatic and zonally symmetric. Water processes are included using Kessler's parameterization (Kessler, 1969). Time integration is performed by a split semi-implicit scheme proposed by Klemp and Wilhelmson (1978). Horizontal and vertical advection terms are approximated by 4 th and 2 nd order schemes, respectively. Horizontal and vertical space resolutions are 2 and $0.5 \mathrm{~km}$, respectively, within a $250 \mathrm{~km} \times 10 \mathrm{~km}$ domain. Top and bottom boundaries are assumed to be rigid. A Sommerfeld-type radiation condition (Orlanski, 1976) is used at the side boundaries to minimize reflection of the gravity waves. Applications of the radiation boundary condition to the convection and mesoscale models have been described by Clark (1977, 1979), Klemp and Lilly (1978) and Klemp and Wilhelmson (1978). In order to test the radiation condition, we chose the problems of propagation of internal gravity waves and (dry) symmetric baroclinic instability (SBI), and compared the solutions between the two domains; $250 \mathrm{~km}$ (horizontal) $\times 10 \mathrm{~km}$ (vertical) and $1000 \mathrm{~km}$ (horizontal) $\times 10 \mathrm{~km}$ (vertical) domain. The solutions in these two different integral domains were sufficiently similar to each other. Thus application of the lateral boundary condition also seems appropriate for the case of the single cell of CSBI circulation. Horizontal and vertical 2nd order viscosity coefficients are set to be 400 and 10 $\left(\mathrm{m}^{2} \mathrm{~s}^{-1}\right)$, respectively, together with a biharmonic 4 th order damper with coefficient of $4 \times 10^{9}$ $\left(\mathrm{m}^{4} \mathrm{~s}^{-1}\right)$ only in the horizontal direction.

\section{b. Initial conditions}

Initial conditions used in this paper are exactly the same as presented in Part I. We assumed an initial zonal wind velocity with linear vertical shear ( 0 and $50 \mathrm{~m} \mathrm{~s}^{-1}$ at the bottom and top boundaries, respectively), which is geostrophically balanced with the meridional 
gradient of virtual potential temperature. In order to focus on CSBI mechanism, an unstable condition for CSBI $\left(R i_{\theta_{e}}=0.26\right.$, in the present case) is satisfied all over the domain ${ }^{1}$. A slight supersaturation of water vapor is imposed generally to drive CSBI circulation, together with random vertical velocity disturbances. No cloud exists initially but appears at the next time step in the initially imposed supersaturation area. See Part I for more details of the initial conditions.

\section{c. Water vapor supply}

In the present experiments, only the equation for the water vapor mixing ratio is different from Part I. A term of water vapor forcing is added to the corresponding equation (2.6) in Part I,

$$
\frac{\partial q_{v}}{\partial t}=-\left(v \frac{\partial q_{v}}{\partial y}+w \frac{\partial q_{v}}{\partial z}\right)+\Delta+E_{r}+D_{q_{v}}+R,
$$

where $q_{v}$ is the mixing ratio of water vapor, $t$ and time, and the meridional and vertical wind velocity, respectively, $\Delta$ the rate of condensation or evaporation of cloud, $E_{r}$ the rate of evaporation of rain, $D_{q_{v}}$ the mixing term, and $R$ the rate of water vapor supply. $R$ is incorporated only at the lowest $q_{v}$ level. Here cooling due to evaporation from the surface is ignored. Water vapor forcing begins at $10 \mathrm{~h}$ after the initial instant when an early stage circulation of CSBI has already built up, since we want to look at how an existing CSBI circulation is modified by the water vapor supply. The rate of water vapor supply is gradually increased up to $11 \mathrm{~h}$ and then kept constant (see Fig. 1). We also made another series of experiment in which

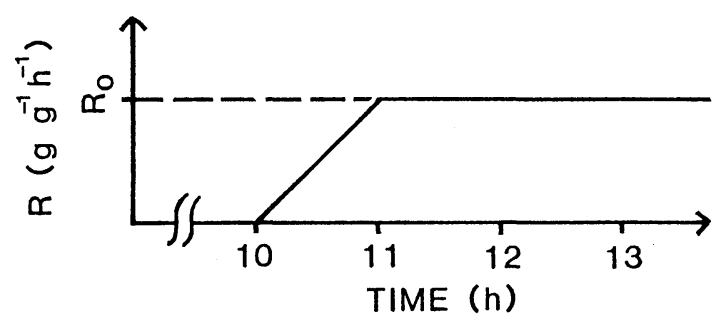

Fig. 1. Time change of the rate of water vapor supply.

1 Equivalent potential vorticity is homogeneous in the domain initially but does not conserve throughout time due to water vapor supply outside of the domain. water vapor supply starts at an initial instant to check whether initially driven convections are organized by subsequently growing CSBI circulation. This result will be shown later for comparison.

We now describe three cases for the experiment. Case $\mathrm{N}$ represents no water vapor supply, which was described in Part I in detail. In Cases S1 and S2, water vapor is supplied at the rates of 3.96 and $6.60 \mathrm{~mm} \mathrm{day}^{-1}$, respectively. Akiyama (1976) estimated the evaporation rate of water vapor from sea surface of the Pacific at the south of Japan in the summer season based on the sea surface temperature and Jacobs's formula. The result shows that the maximum rate of evaporation is about $6 \mathrm{~mm}$ day $^{-1}$. The range of evaporation rate used in this experiment is reasonable for sea surface evaporation throughout the year except for the large evaporation rate in the tropics.

\section{Results and discussions}

Our main concern in the present paper is to see how the cloud and rainfall patterns are modified by the water vapor supply from the surface, together with deformation of stratification.

\section{a. Time evolution of cloud patterns}

Time evolutions of the cloud pattern for Cases $\mathrm{N}, \mathrm{S} 1$ and S2 are shown in Figs. 2, 3 and 4, respectively.

A detailed description of Case $\mathrm{N}$ is given in Part I and which is summarized here briefly. In Fig. 2, a weak but widely extended cloud is seen at the center portion of the domain, which originated from the imposed supersaturation of the initial water vapor field. At $12 \mathrm{~h}$, a slantwise stratiform cloud starts growing independently of the initial cloud between 4 and $6 \mathrm{~km}$. It grows both upward and northward with increasing cloud water content. The initial cloud at the center portion gradually fades out and finally disappears at $24 \mathrm{~h}$. At 30 and $31 \mathrm{~h}$, convective cells (indicated by arrows in Fig 2) begin to grow in the mid-tropospheric convectively unstable layer induced by CSBI circulation. These convective clouds can be identified as generating cells which play an important roles in the rainfall mechanism of stratiform clouds (when ice pro- 


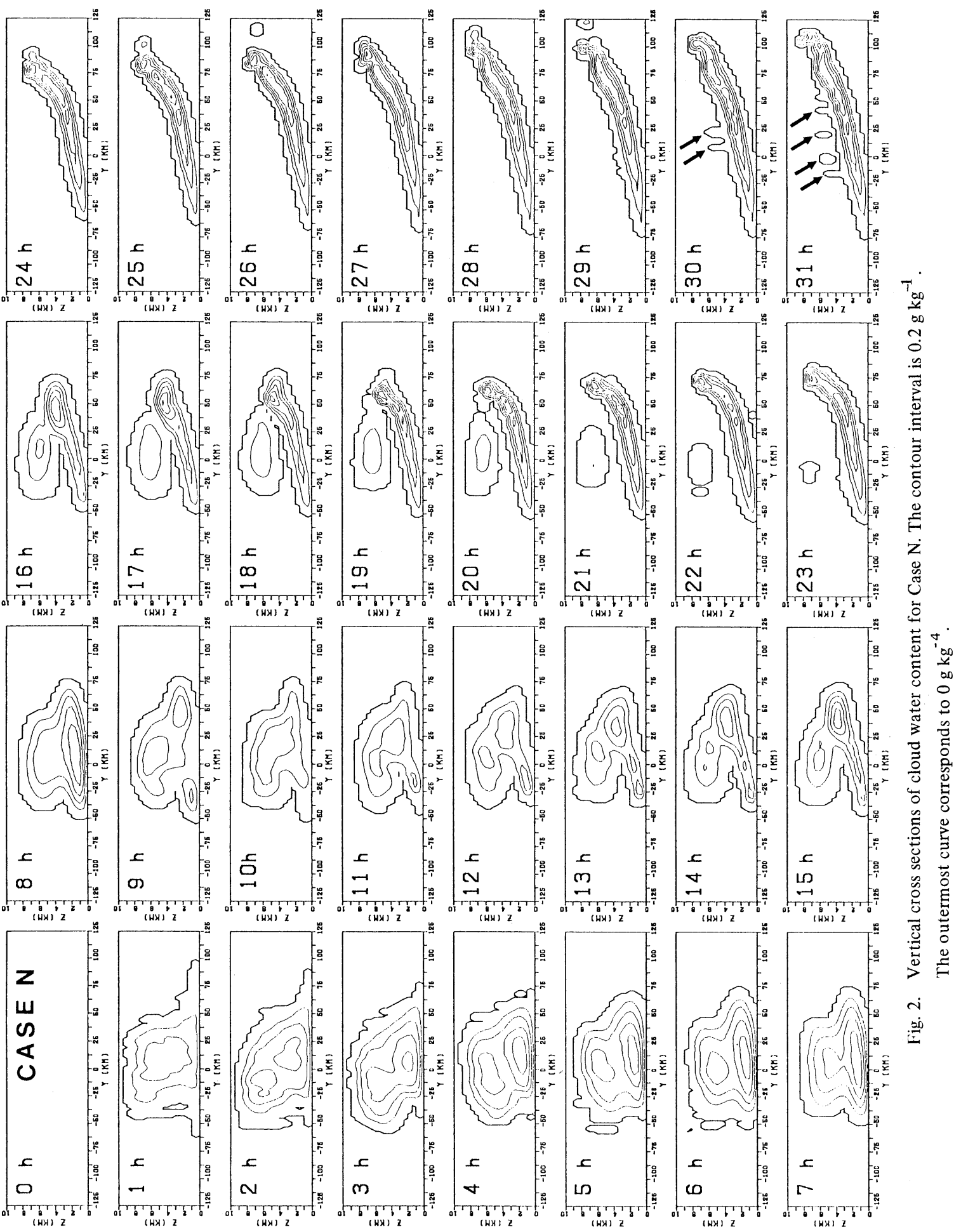




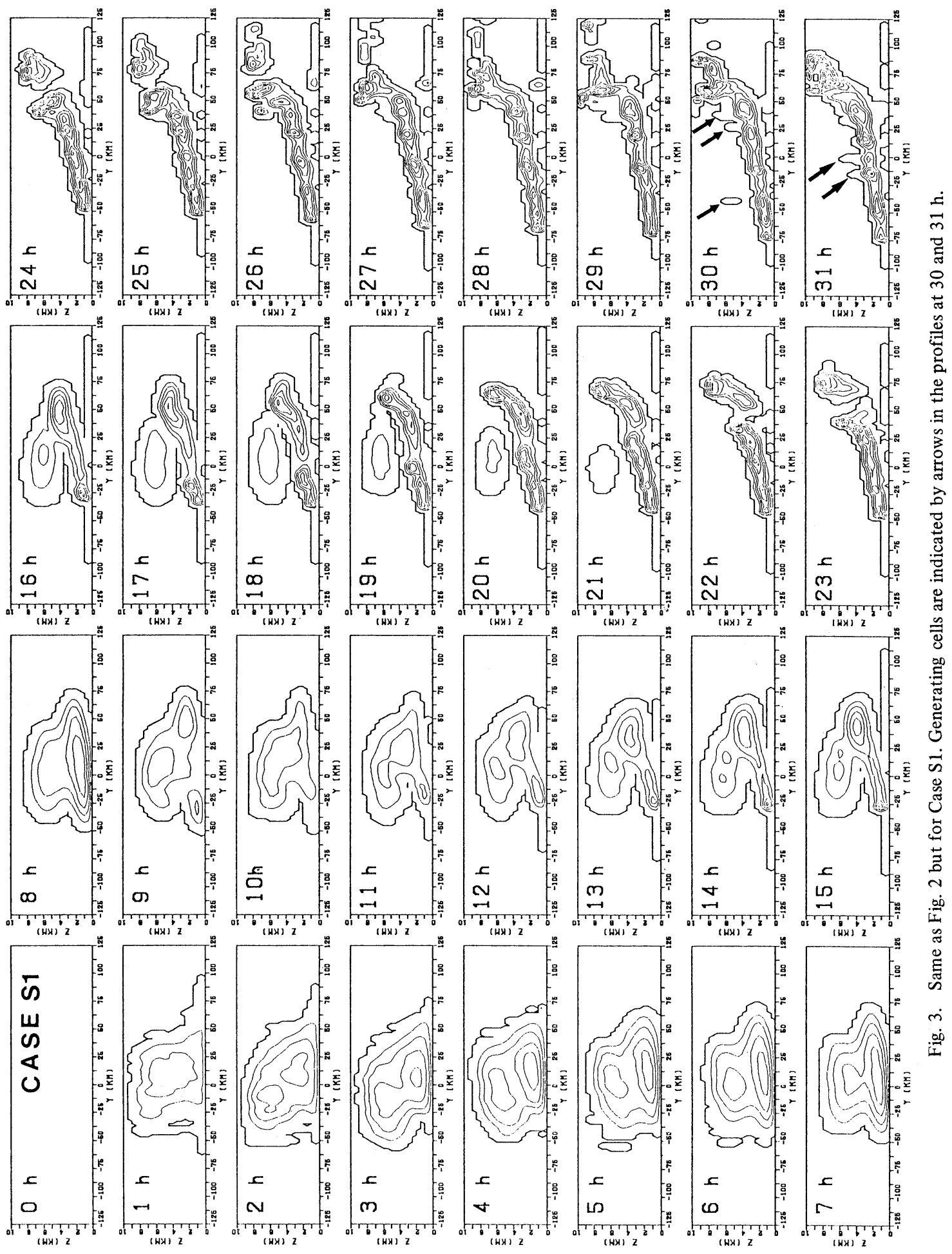


cesses are included and the horizontal resolution is improved in the model).

In Case S1, in which the rate of water vapor supply is small, development of the slantwise cloud pattern (see Fig. 3) is still similar to Case N. A slantwise cloud grows from the bottom of the center portion of the domain and extends northward. A segment of cloud formed by the initially incorporated supersaturation fades out at $22 \mathrm{~h}$ in Case $\mathrm{S} 1$, but at $24 \mathrm{~h}$ in Case $\mathrm{N}$. Detailed inspection shows, however, that several nodes of cloud density appear in the slantwise cloud with a horizontal spacing of 25 to $40 \mathrm{~km}$. These nodal cloud cells are closed convective cells, which can potentially develop to more typical convections as will be stated later. At the top edge of the slantwise cloud, a large convective cloud begins to appear at $22 \mathrm{~h}$ and grows vertically as time elapses. Note that this type of active convective cloud does not grow in Case N. Small scale convective cells indicated by arrows (which are regarded as generating cells) are formed above the slantwise cloud after $30 \mathrm{~h}$. These cells are rather weaker in activity than the convective cells appearing at the top edge of slantwise cloud.

More drastic modification is observed in Fig 4 when the rate of water vapor supply is increased (Case S2). A large convective cell begins to grow at the convergence zone of the slantwise cloud at $14 \mathrm{~h}$ and rapidly develops upward. Development of the slantwise cloud pattern is strongly suppressed. The initially imposed cloud begins to fade at $16 \mathrm{~h}$ and disappears at $19 \mathrm{~h}$. Finally, large cumulus clouds are formed at the convergence zone of CSBI circulation together with several cloud clusters. It is noted that the roots of the convective cloud clusters are aloft at the mid-tropospheric level except for the southmost convective cloud. These clouds are formed by the elevation of enhanced cloud nodes which grow originally in the updraft region of CSBI circulation. This fact suggests that the slantwise structure due to CSBI circulation still plays some role in developing convective cloud clusters, though the slantwise stratiform cloud is broken down in the early stage. The most active convections are serially generated for more than 10 hours. It is an interesting feature that the convections continue such a long period.
From the standpoint of heat (equivalent potential temperature) transport, the modification of the cloud pattern due to water vapor supply are realized as follows. When water vapor is not supplied, the resultant circulation is slantwise so as to transport heat both upward and northward to relax the small imbalance of heat in both directions. Upward transport of heat stabilizes the stratification in the vertical direction. On the other hand, northward heat transport reduces the meridional gradient of heat, and hence the vertical shear of the zonal wind is reduced. If water vapor is supplied from the bottom, the vertical imbalance of heat is enhanced sustaining the horizontal gradient of equivalent potential temperature. If the water vapor supply is large enough, convective clouds must grow to compensate the vertical heat imbalance efficiently. This is the reason why the convective clouds prevail as the rate of water vapor supply increases. By and large, heat is still transported through the slantwise cloud in Case $\mathrm{S} 1$, while the major heat transport is through the large convective cloud in Case S2.

\section{b. Rainfall pattern on the surface}

Meridional distance - time cross sections of rainfall intensity on the lowest grid level $(z=$ $250 \mathrm{~m}$ ) are shown in Figs. 5, 6 and 7 for Cases $\mathrm{N}, \mathrm{S} 1$ and $\mathrm{S} 2$, respectively. In the case of no water vapor supply (Case N) as shown in Fig. 5, a weak precipitation region with a rainfall intensity larger than $0.1 \mathrm{~mm} \mathrm{~h}^{-1}$ (indicated by broken curves) extends more than $100 \mathrm{~km}$ to the meridional direction (see Part I in more detail). The stronger but narrower precipitation region with maximum rainfall intensity less than $5 \mathrm{~mm} \mathrm{~h}^{-1}$ is seen near the north edge of the weak precipitation region which is formed by the rain from the top region of the slantwise cloud.

Water vapor supply changes this rainfall pattern as shown in Figs. 6 and 7. In Case S1 (see Fig. 6), weak rainfall area $\left(R I>0.1 \mathrm{~mm} \mathrm{~h}^{-1}\right)$ extends more than $100 \mathrm{~km}$ as in Case $\mathrm{N}$ (see Fig. 5). A significant difference from Case $\mathrm{N}$ is observed after $16 \mathrm{~h}$. At $16 \mathrm{~h}$, a region indicated by (0) where the rainfall intensity exceeds $2 \mathrm{~mm}$ $\mathrm{h}^{-1}$ appears just inside of the south edge of 0.1 $\mathrm{mm} \mathrm{h}^{-1}$ contour line and moves northward. As time elapses, five branches of narrow and strong 


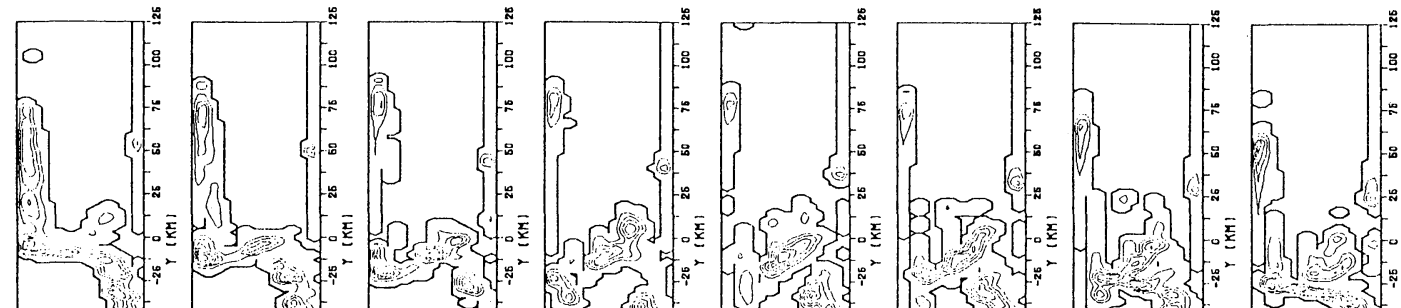
(6)

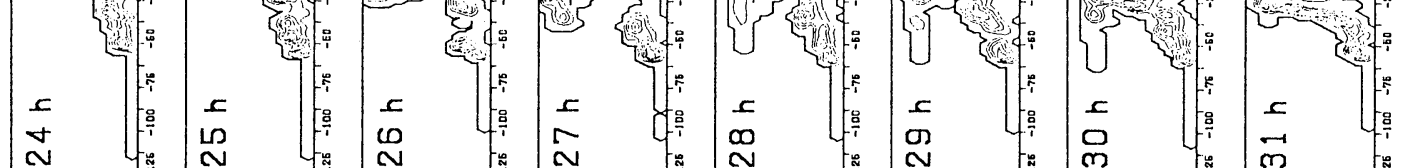

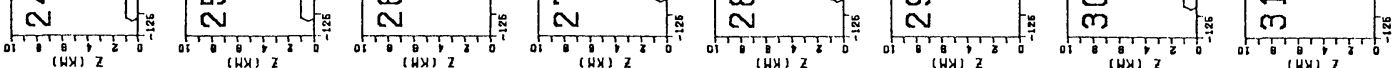

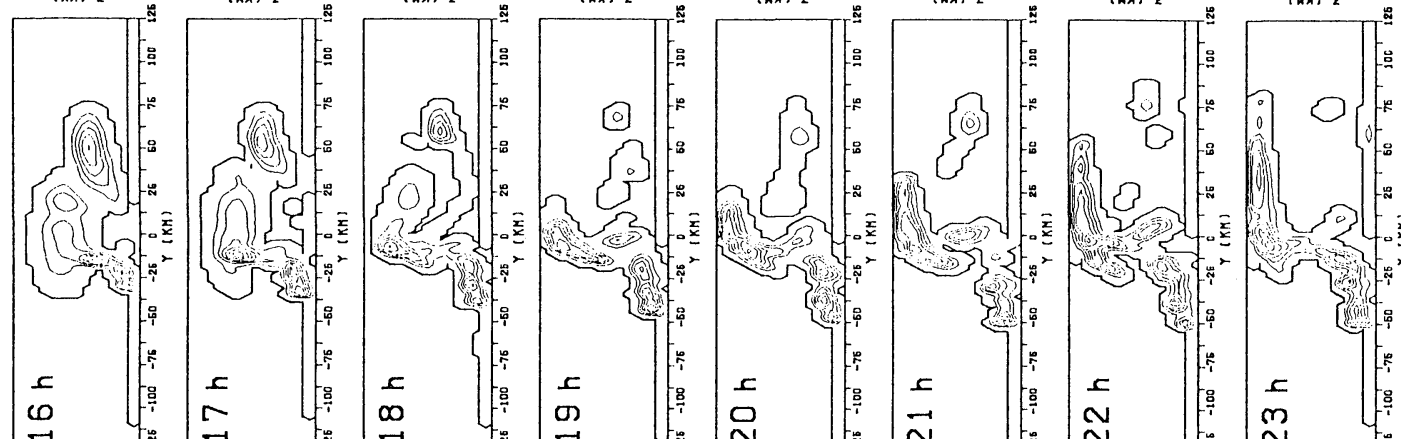

$\because$ Or
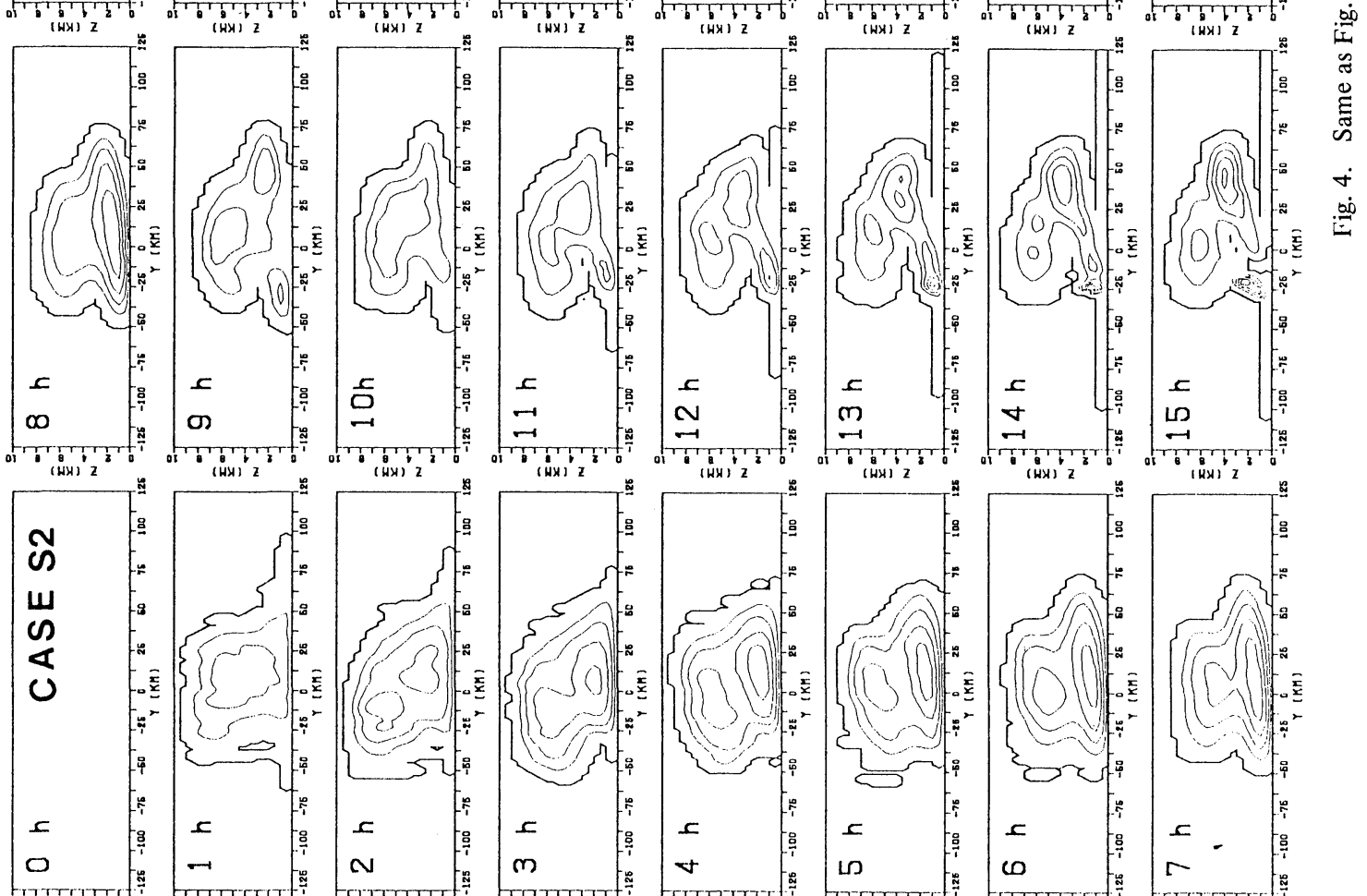

वा

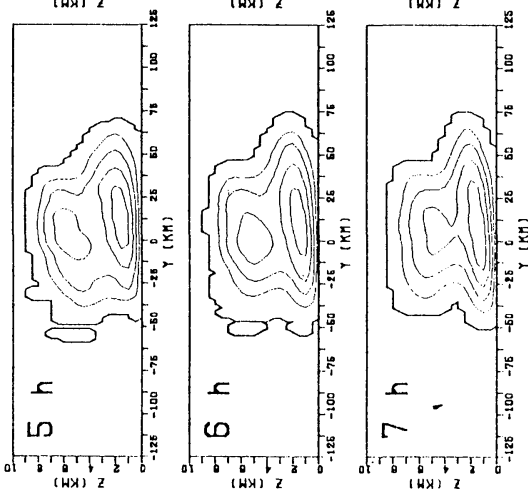




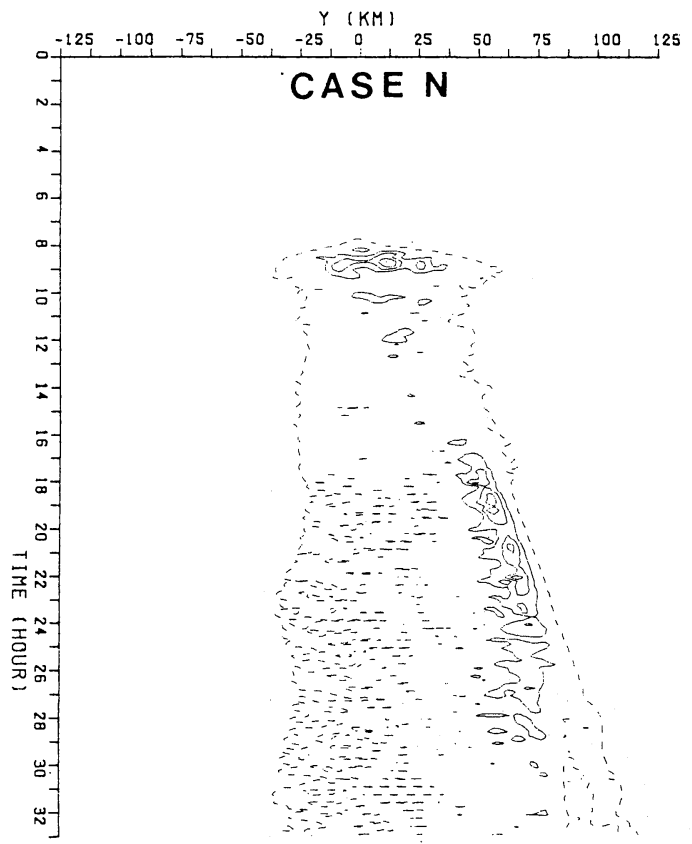

Fig. 5. Horizontal distance - time section of rainfall intensity at the lowest grid level $(z=250 \mathrm{~m})$ for Case $\mathrm{N}$. Broken curves show $0.1 \mathrm{~mm} \mathrm{~h}^{-1}$. The contour interval of solid curves is $2 \mathrm{~mm} \mathrm{~h}^{-1}$.

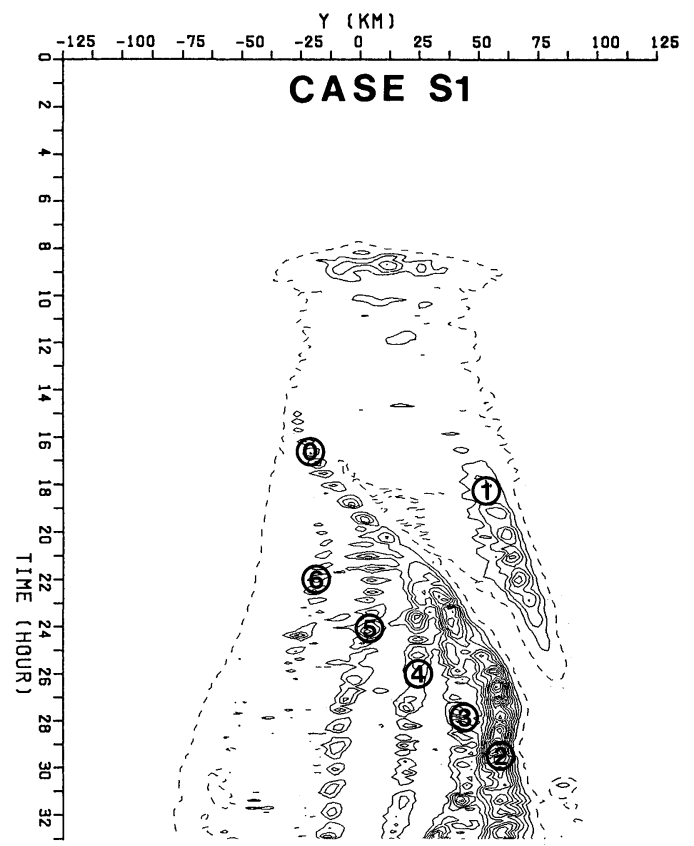

Fig. 6. Same as Fig. 5 but for Case S1. precipitation bands appear from the precipitation area (0) with about $25 \mathrm{~km}$ spacing in the meridional direction as indicated by (2) - (6) in Fig. 6. Among these five bands, the northmost one indicated by (2) is the strongest in rainfall intensity which exceeds $10 \mathrm{~mm} \mathrm{~h}^{-1}$ and reaches $16 \mathrm{~mm} \mathrm{~h}^{-1}$. As was stated before, this precipitation region is associated with the strong convective type cell developed aloft at the top edge of the slantwise cloud. Rainfall intensity never exceeds $10 \mathrm{~mm} \mathrm{~h}^{-1}$ in the other four weaker bands indicated by (3) - (6). These bands are associated with nodal cloud cells embedded in the slantwise stratiform cloud (see Fig. 3). Within these narrow precipitation region, oscillations of the rainfall intensity with the period of about an hour are seen. These nodal cloud cells can, with care, be observed in the frontal rainfall areas.

When the most water vapor is supplied (Case S2), the weak rainband where rainfall intensities exceed $0.1 \mathrm{~mm} \mathrm{~h}^{-1}$ suddenly decreases in width in the meridional direction at $15 \mathrm{~h}$ (see Fig. 7) due probably to the breakdown of the slantwise cloud associated with CSBI circulation. A strong

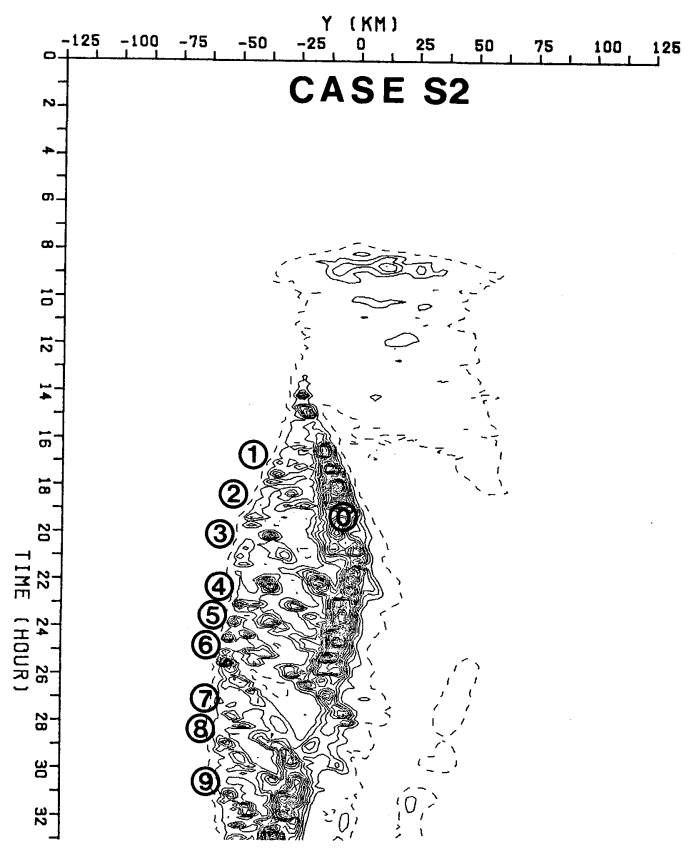

Fig. 7. Same as Fig. 5 but for Case S2. 
precipitation region indicated by (0) in Fig. 7 appears at the foot of the slantwise cloud and forms heavy rainfall with an intensity of more than $50 \mathrm{~mm} \mathrm{~h}^{-1}$. This rainband moves slightly northward and then southward. Narrow and strong precipitation regions indicated by (1) (9) appear after $17 \mathrm{~h}$ from the south edge of the contour of $0.1 \mathrm{~mm} \mathrm{~h}^{-1}$. They propagate northward and merge with the main precipitation band (0) within a few hours. The strong precipitation regions are clearly associated with a big cumulus convective cloud developed at the convergence zone of CSBI circulation and several cloud clusters in it. More detailed features must wait until a three-dimensional treatment has been done.

Thus, as the rate of water vapor supply increases the main precipitation region becomes narrow and precipitation intensity is enhanced. A variety of precipitation patterns develop, according to the water vapor supply.

\section{c. Stratification}

Cross sections of the vertical gradient of the equivalent potential temperature averaged 12 to $16 \mathrm{~h}, 20$ to $24 \mathrm{~h}$ and 28 to $32 \mathrm{~h}$ for Cases N, S1 and $\mathrm{S} 2$ are shown in Figs. 8a, b, c, 9a, b, c and $10 \mathrm{a}, \mathrm{b}, \mathrm{c}$, respectively. Convectively unstable regions are shaded in each figure. The solid and broken curves show positive and negative contours, respectively, at intervals of $0.5 \mathrm{~K} \mathrm{~km}^{-1}$.

In Fig. 8a, very weak convectively unstable regions are seen at $\mathrm{z}=4 \mathrm{~km}$ near the right boundary. At the initial growing stage, the convectively unstable layer is $1 \mathrm{~km}$ in thickness around the altitude of $4 \mathrm{~km}$ extending from $y=0$ to $70 \mathrm{~km}$. The unstable layer develops and extends from the center of the domain to the right boundary in Fig. 8b. In Fig. 8c, the strong unstable region is formed slantwisely from $y=25$ to $70 \mathrm{~km}$ and between $z=4$ and $7 \mathrm{~km}$. Below the unstable layer, an enhanced stable layer is seen from $y=-40 \mathrm{~km}$ to the right boundary. The most unstable region moves northward and upward above the slantwise stratiform cloud. Below the convectively unstable layer, a stable layer extends widely. Another stable layer is also observed above the mid-tropospheric convectively unstable layer.

A weak convectively unstable layer is formed
CASE N
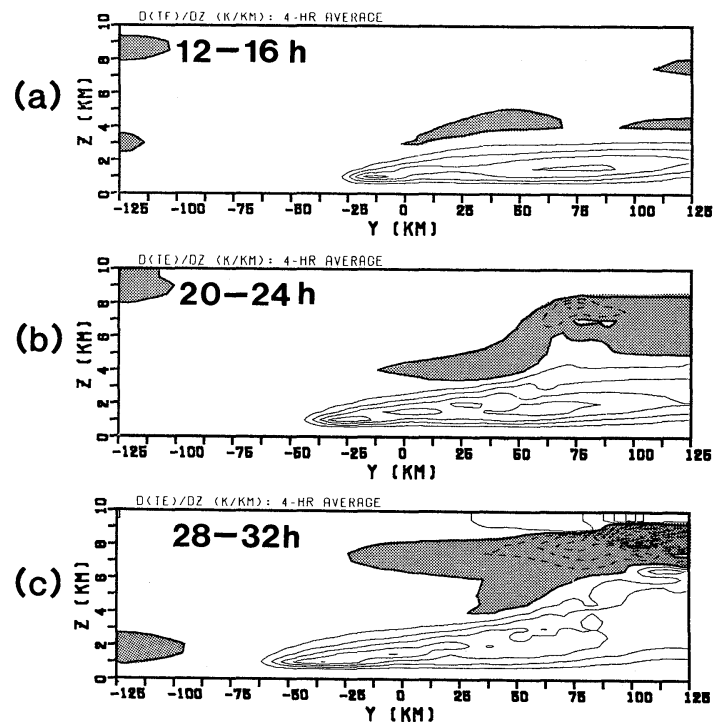

Fig. 8a. Vertical gradient of equivalent potential temperature for Case $\mathrm{N}$ averaged for 12 to $16 \mathrm{~h}$. Convectively unstable regions are shaded. Solid and broken curves show positive and negative contours, respectively. The contour interval is $1 \mathrm{~K} \mathrm{~km}^{-1}$.

Fig. 8 b. Same as Fig. 8 a but for the period 20 to $24 \mathrm{~h}$. Fig. 8c. Same as Fig. 8a but for the period 28 to $32 \mathrm{~h}$.

CASE S1
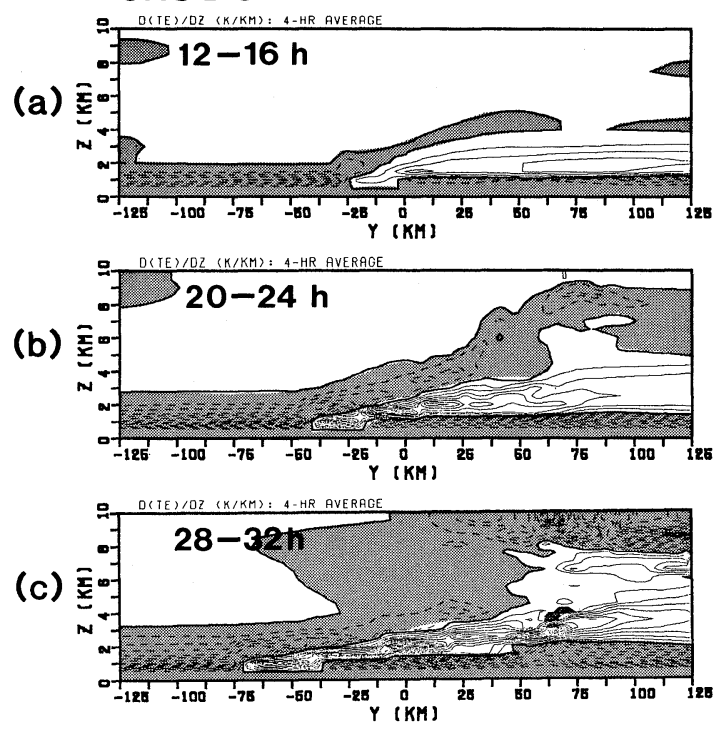

Fig. 9a. Same as Fig. 8a but for Case S1.

Fig. 9b. Same as Fig. 8 b but for Case $\mathrm{S} 1$.

Fig. 9c. Same as Fig. 8c but for Case S1. 
due to the water vapor supply near the surface below $2 \mathrm{~km}$ in Case S1 (see Fig. 9a). Another convectively unstable layer extends above the slantwise stratiform cloud, which merges with the bottom unstable layer. This mid-tropospheric convectively unstable layer is much thicker when water vapor is supplied (cf. Fig. 8a). The convectively unstable layer in the mid-troposphere is enhanced by the transport of supplied water vapor along the slantwise updraft of the CSBI circulation. Thus, the slantwise updraft works as a meso- $\beta$ scale warm conveyer belt which transports water vapor efficiently from low level to the mid-troposphere. Stratification is stabilized below the mid-tropospheric convectively unstable layer. The discrepancy of stability is enhanced as time elapses (see Fig. 9b and 9c). Finally, convective instability becomes sensible due to upward motion at the top edge of the slantwise cloud (see Fig. 3) and a large convective cloud begins to develop. As shown later, the slantwise convectively unstable layer is deeply related to the formation of nodal clouds (see Fig. 3).

In Cases $\mathrm{S} 2$, the bottom convectively unstable layer and the slantwise convectively unstable layer are also seen (see Fig. 10a) as in Case S1

\section{CASE S2}

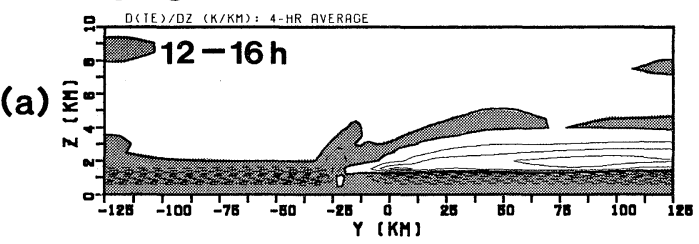

(b)
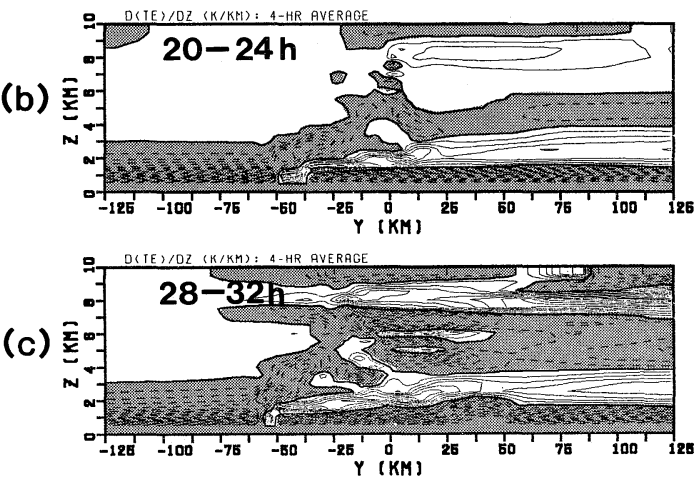

Fig. 10a. Same as Fig. 8a but for Case S2.

Fig. 10b. Same as Fig. $8 \mathrm{~b}$ but for Case S2.

Fig. 10c. Same as Fig. $8 \mathrm{c}$ but for Case S2.
(Fig. 9a). In this case, however, the convective instability is strong enough to produce convective clouds even during 12 to $16 \mathrm{~h}$ if small upward motions are enforced by CSBI circulation. The development of the convectively unstable layers are seen in Fig. 10b, in which enhancements of the instability both in the bottom and mid-tropospheric convectively unstable layers are very strong. In Fig. 10c, it is evident that the slantwisely extended mid-tropospheric convectively unstable layer is still enhanced. Although a slantwise structure is not clearly seen in the cloud pattern, Fig. 10a, b and c suggest the existence of the slantwise circulation of CSBI, no matter how weak. In fact, a slantwise structure also appears in the wind velocity fields, but is not shown here. When large amounts of water vapor are supplied, the convergence associated with CSBI circulation initiates large cumulus clouds and hence forms a rainband with heavy rainfall along the front.

\section{d. Cloud and convectively unstable region}

Figure 11 shows the locations of cloud and convectively unstable regions for Case N. In Fig. $11 \mathrm{a}$, a thin convectively unstable layer is seen at the top portion of the slantwise cloud. It should be noted in Fig. 11b that the upper portion of the slantwise cloud is convectively unstable. In Fig. 11c, convective instability disappears in the layer where generating cells are seen. Then the convective instability is sufficiently stabilized by weak convections such as generating cells.

In Case S1, a convectively unstable layer in the mid-troposphere merges with the bottom convectively unstable layer in Fig. 12a. The convectively unstable layer invades into the slantwise cloud more deeply than in Case N (Fig. $12 \mathrm{~b}$ ); then nodes of the cloud density can be identified as closed convective cells. As time elapses the slantwise convectively unstable layer moves slowly upward (see Fig. 12c).

When the most water vapor is supplied (Case $\mathrm{S} 2$ ), patterns of cloud and convectively unstable regions at $14 \mathrm{~h}$ are rather similar to Case $\mathrm{S} 1$ (see Fig. 13a). After $16 \mathrm{~h}$, however, a large convective cloud begins to grow vertically (see Fig. 4) and then develops (see Fig. 4 and Fig. 13b). We would like to stress that the slantwise con- 
CASE N

(a)

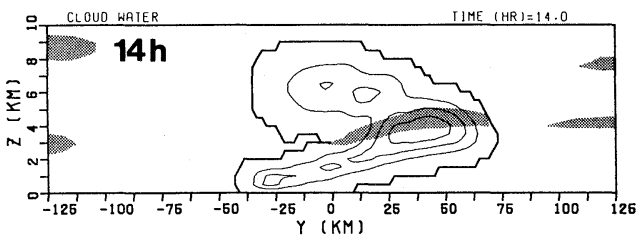

(b)

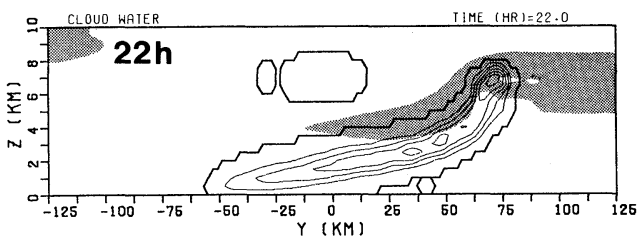

(c)

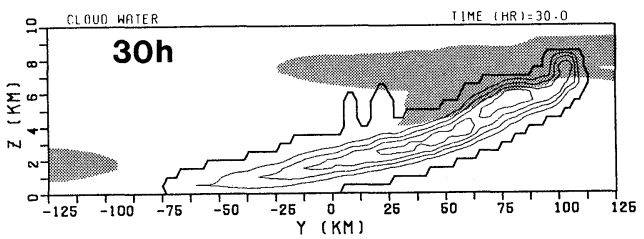

Fig. 11a. Profiles of the cloud water content at $14 \mathrm{~h}$ and convectively unstable region averaged 12 to $16 \mathrm{~h}$. Thick solid curve shows the zero contour of cloud water content. Thin solid curve shows the contour of cloud water content with interval of $0.2 \mathrm{~g} \mathrm{~kg}^{-1}$. Convectively unstable regions are shaded.

Fig. 11b. Same as Fig. 11a but for the cloud water content at $22 \mathrm{~h}$ and convectively unstable region averaged 20 to $24 \mathrm{~h}$.

Fig. 11c. Same as Fig. 11a but for the cloud water content at $30 \mathrm{~h}$ and convectively unstable region averaged 28 to $32 \mathrm{~h}$.

vectively unstable layer is formed as in Cases $\mathrm{N}$ and $\mathrm{S} 1$.

\section{e. Nodes of cloud density}

In Case $\mathrm{S} 1$, nodes of cloud density are observed within the slantwise cloud. We have performed an analysis along a straight slantwise surface which lies parallel to the slantwise cloud (see Fig. 14).

Figure 15 shows the time change of cloud density along the slantwise straight line. Following $13 \mathrm{~h}$, a high cloud water content appears at $y=-25 \mathrm{~km}$, which is divided into two branches indicated by (0) and (8). Many branches of high cloud water content, indicated by (2) (7), are formed with a horizontal separation of 20 to $30 \mathrm{~km}$ as time elapses. Lines of large cloud water content labeled by (2) - (8) correspond to
CASE S1

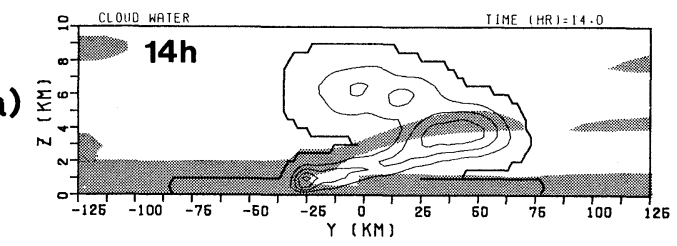

(b)

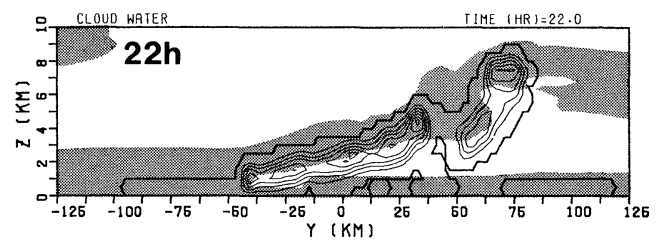

(c)

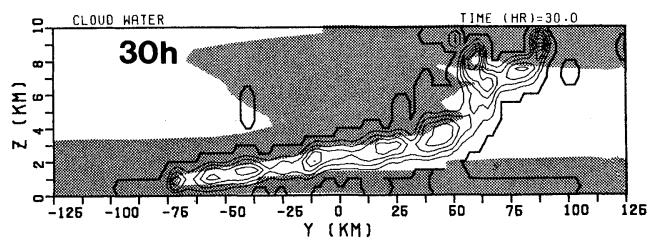

Fig. 12a. Same as Fig. 11a but for Case S1.

Fig. 12b. Same as Fig. 11b but for Case S1.

Fig. 12c. Same as Fig. 11c but for Case S1.

\section{CASE S2}

(a)

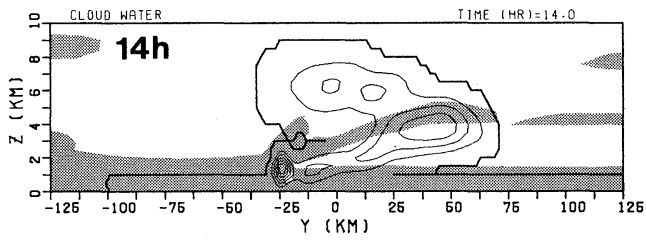

(b)
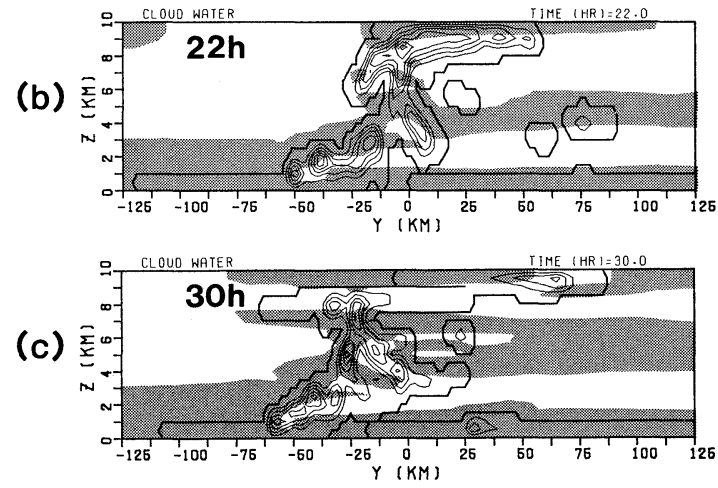

Fig. 13a. Same as Fig. 11a but for Case S2.

Fig. 13b. Same as Fig. 11b but for Case S2.

Fig. 13c. Same as Fig. 11c but for Case S2.

the cloud nodes seen in Fig. 3. The lines (2) (6) correspond to the precipitation lines with respective numbers in Fig. 6. 


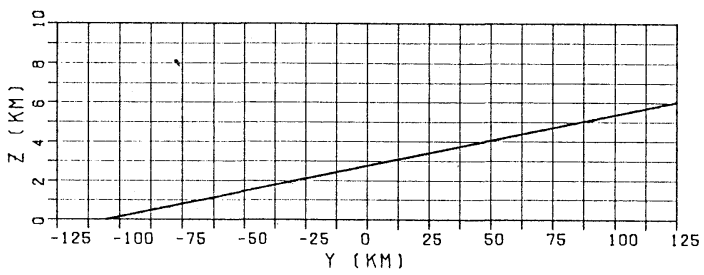

Fig. 14. A slantwise straight line along which the analyses of the data are made.

\section{CASE S1 (along the slantwise line)}

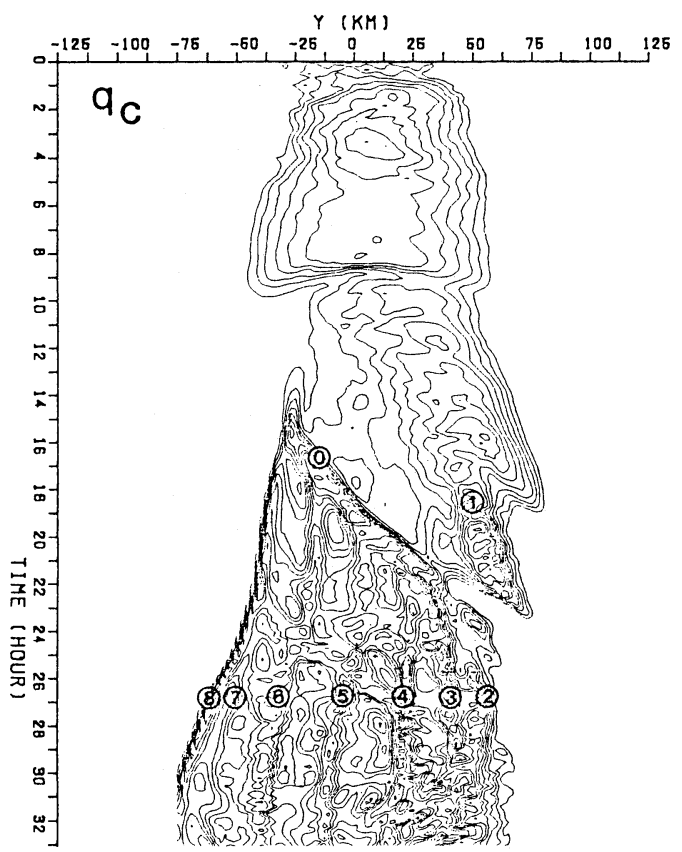

Fig. 15. Time change of the cloud water content along the slantwise straight line. The contour interval is 0.1 $\mathrm{g} \mathrm{kg}^{-1}$.

Time evolution of vertical velocity on the slantwise straight line is given in Fig. 16. Lines of large upward velocity regions labelled by (0) (8) correspond to the large cloud density lines labelled by the respective numbers in Fig 15. Weak downdrafts are sometimes seen between updrafts. Careful observation leads to an oscillation with a period of 1 to $2 \mathrm{~h}$ within each line of strong updraft. Gravity waves with short horizontal wavelength (10 to $20 \mathrm{~km}$ ) prevail in the domain (Fig. 16). These gravity waves are likely to be trapped due to the short horizontal wavelength, that is, external gravity waves.
CASE S1 (along the slantwise line)

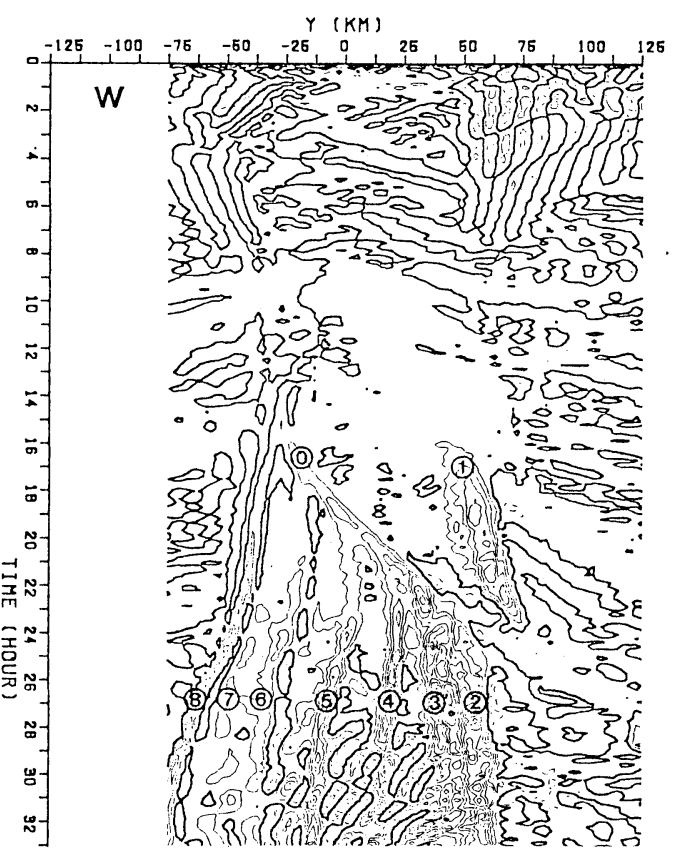

Fig. 16. Time change of the vertical velocity along the slantwise straight line. The contour interval is $0.1 \mathrm{~m}$ $\mathrm{s}^{-1}$.

However, in the real atmosphere gravity waves with such a short wavelength cannot propagate upward through the tropopause. Then the top rigid boundary condition is a reasonable expression of the behaviour of the short wavelength gravity waves. Gravity waves generated by the initial random disturbance do not survive after $10 \mathrm{~h}$. Gravity waves in evidence after $10 \mathrm{~h}$ are physically realistic. The horizontal scale of the gravity waves is similar to that of the nodal clouds seen in Case S1. However, it is beyond the scope of this paper to conclude the mutual relation between the gravity waves and nodal clouds together with the generating mechanism.

Fig. 17 shows the time evolution of the vertical gradient of equivalent potential temperature on the same slantwise line. The convectively unstable region is shaded. In the early stage no convectively unstable region is seen because the initial field is convectively stable all over the integration domain. A convectively unstable region is observed after $10 \mathrm{~h}$. Lines of dense cloud shown in Fig. 15 and those of strong 
CASE S1 (along the slantwise line)

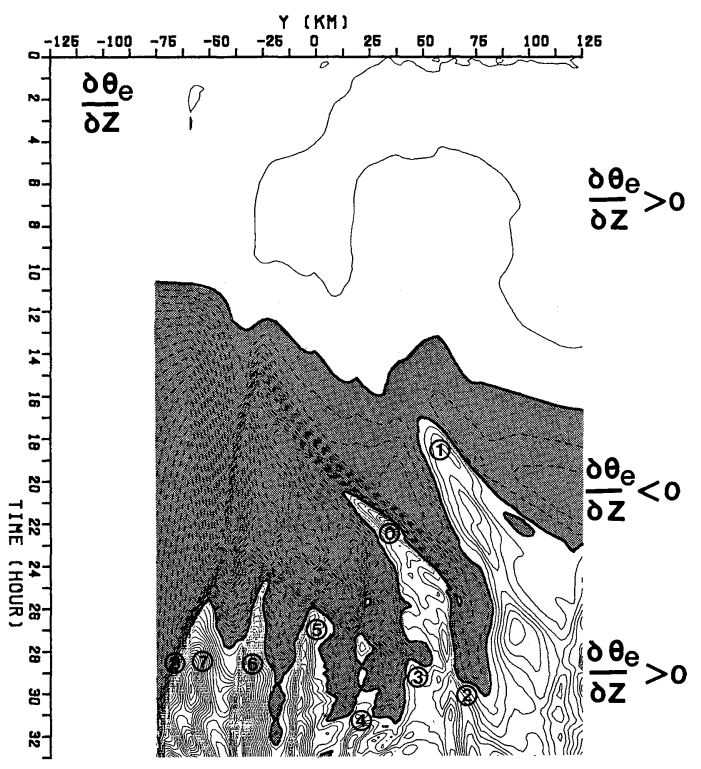

Fig. 17. Time change of the vertical gradient of the equivalent potential temperature along the slantwise straight line. Thin solid and broken curves are positive and negative contours with the interval of $0.25 \mathrm{~K} \mathrm{~km}^{-1}$, respectively. Convectively unstable region is shaded.

updraft shown in Fig. 16 are initiated slightly after the convective instability appears. As time elapses, wedge-shaped strong convectively stable regions appear, which are labelled by numbers within a circle. Within a short period all the region will become stabilized. These wedgeshaped convective stable regions correspond to both lines of high cloud density in Fig. 15 and strong updraft in Fig. 16 labelled by the same numbers. The nodal cloud cells transport heat upward and, as a result, stabilize the stratification. As seen in Fig. 12, the slantwise convectively unstable layer moves slightly upward and is sustained as long as water vapor supply continues after the convective instability disappears on the slantwise straight line. Thus, the nodal cloud cells still continue to be maintained in the slantwise cloud. We can say that the nodal cloud cells seen in Case S1 eventually become shallow convective cells embedded in the slantwise cloud.

f. The role of CSBI circulation in developing and organizing convective clouds
In Part I, we presented the role of CSBI circulation from the view point of formation of the stratiform type rainband. Present experiments show that CSBI circulation can play roles in organizing convective cells on the meso-scale. First, low-level convergence of CSBI circulation triggers large convective clouds in a concentrated region when the water vapor supply is large. Second, CSBI circulation forms shallow convective cells in the slantwise cloud when water vapor supply is moderate. Third, CSBI circulation produce generating cells above the slantwise cloud even when water vapor supply is very small.

\section{g. Water vapor forcing}

Finally, we must describe briefly what will happen if we start water vapor forcing from the outset. A comparison of cloud pattern at the same time $(24 \mathrm{~h})$ is shown in Fig. 18a and b in Case S1. The cloud patterns are very similar to each other except that anvil clouds prevail in the case of initial forcing. When water vapor is enforced from the outset, the convective cloud at the top portion of the slantwise cloud grows more rapidly. As time elapses, CSBI circulation begins to organize the convective clouds into a slantwise pattern. Even when water vapor supply is large, both patterns become similar though they are not shown here. The initiation time of water vapor forcing is not likely to cause any large difference to the final cloud pattern.

(a)

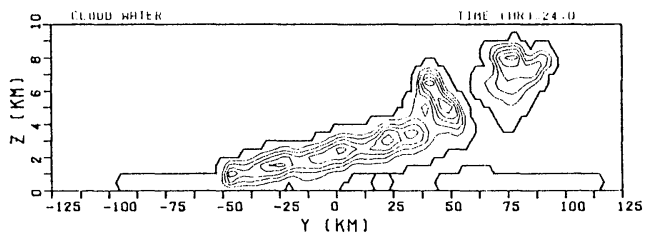

(b)

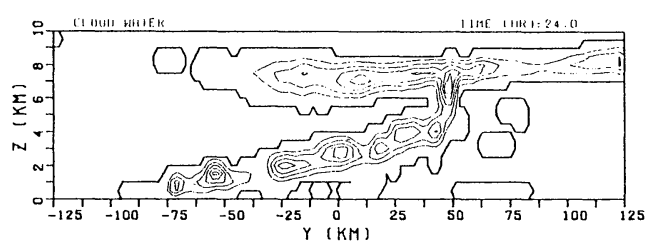

Fig. 18a. Profile of cloud water content at $24 \mathrm{~h}$ for Case $\mathrm{S} 1$, in which water vapor forcing starts from $10 \mathrm{~h}$. Thick curves show zero contours. Contour interval of thick curves is $0.2 \mathrm{~g} \mathrm{~kg}^{-1}$.

Fig. 18b. Same as Fig. 18a but for water vapor forcing from the outset. 


\section{Conclusions}

Numerical experiments of CSBI are made to study how the low level water vapor supply modifies the CSBI circulation. The study is important to better understand the possible role which CSBI plays in forming rainbands at frontal zones. The numerical model and initial conditions are the same as that presented in Part I. Water vapor is supplied from a low level. Three cases are investigated. The solutions of two cases with different water vapor supply are compared with that of no water vapor supply. The main conclusions of the present study are as follows: (i) When the rate of water vapor supply is moderate (Case S1), a slantwise structure of cloud along the updraft of CSBI circulation is clearly formed and sustained. Weak generating cells are also seen above the slantwise cloud. Thus the slantwise cloud also includes nodes of cloud density with horizontal interval of 20 to $30 \mathrm{~km}$. These cloud nodes are regarded as induced by shallow convective cells: When the rate of water vapor supply increases (Case S2), large convective clouds develop at the convergence zone of the CSBI circulation and in the slantwise convectively unstable layer. Active convections are seen there for more than 10 hours.

(ii) A weak precipitation region (RI $>0.1 \mathrm{~mm}$ $\mathrm{h}^{-1}$ ) extends over $100 \mathrm{~km}$ in the meridional direction when water vapor is supplied moderately (Case S1), which is similar to the case of no water vapor supply. Several strong and narrow precipitation regions are observed, being embedded in the weak but wide rainband. These concentrated rainbands are generated by the nodal cloud cells induced in the slantwise cloud. When the water vapor supply is large, the precipitation region becomes narrow but the rainfall intensity is enormously enhanced by the CSBIinduced cumulus convections.

(iii) Even when the rate of water vapor supply is large, a convectively unstable layer appears slantwisely at the mid-troposphere. This fact suggests that the CSBI circulation is still sustained and works to organize convections on the meso- $\beta$ scale.

A two-dimensional model has been used here.
However, it would be reasonable to consider that the convections triggered or induced by CSBI circulation will concentrated on band along the symmetric axis of CSBI circulation, because the CSBI circulation itself has a symmetric nature even in a three-dimensional field.

We have attempted to show in this paper that baroclinicity is influencial in organizing convective clouds into mesoscale structures in the frontal zone. Combined effects of baroclinicity in the moist atmosphere and water vapor supply produce great varieties of cloud and rainfall patterns. We would suggest that our methods provide a valuable new approach to the study of certain mesoscale phenomena.

\section{Acknowledgments}

We would like to thank Prof. A. Ono of Nagoya University for ceaseless encouragement, to Prof. T. Takeda of Nagoya University and Dr. M. Yoshizaki of Tokyo University for valuable critical comments, to Dr. Y. Ishizaka of Nagoya University for discussions and encouragement, and to Messrs. K. Nakajima of Tokyo University and M. Ikawa of Meteorological Research Institute for useful comments in the preliminary stage of the present study. The numerical calculations were carried out using FACOM M 382 and VP100 computers of the Nagoya University Computation Center. This study was partly supported by Grant-in-Aid for Research in Natural Disasters (No. A-61-3) by the Ministry of Education.

\section{References}

Akiyama, T., 1973: The large-scale aspects of the characteristic features of the Baiu Front. Pap. Meteor: Geophys., 24, 157-188.

- 1975: Southerly transversal moisture flux into the extremely heavy rainfall zone in the Baiu season. J. Meteor. Soc. Japan, 53, 304-316.

- 1978: Mesoscale pulsation of convective rain in medium-scale disturbances developed in the Baiu front. J. Meteor. Soc. Japan, 56, 267-283.

, 1979: Thermal stratification in Baiu frontal medium-scale disturbances developed in Baiu season. J. Meteor. Soc. Japan, 57, 587-598.

Bennets, D.A., and B.S., Hoskins, 1979: Conditional symmetric instability - a possible explanation for frontal rainbands. Quart. J. Roy. Meteor. Soc., 105, 945-962. 
, and P. Ryder, 1984: A study of mesoscale convective bands behind cold fronts. Part I: Mesoscale organization. Quart. J. Roy. Meteor. Soc., 110, 121-145.

Clark, T.L., 1977: A small-scale dynamical model using a terrain following coordinate transformation. $J$. Comput. Phys., 24, 186-215.

- 1979: Numerical simulations with a threedimensional cloud model: Lateral boundary condition experiments and multicellular severe storm simulations. J. Atmos. Sci., 36, 2191-2215.

Emanuel, K.A., 1979: Inertial instability and mesoscale convective system. Part I. Linear theory of inertial instability. J. Atmos. Sci., 36, 2425-2449.

, 1983: The Lagrangian parcel dynamics of moist symmetric instability. J. Atmos. Sci., 40, 2368-2376.

Hobbs, P.V., 1978: Organization and structure of clouds and precipitation on the mesoscale and microscale in cyclonic storms. Rev. Geophys. Space Phys., 16, 741-755.

Houze, R.A., Jr., and P.V. Hobbs, 1982: Organization and structure of precipitating cloud system. $A d v$. Geophys., 24, 225-315.

Kessler, E., 1969: On the distribution and continuity of water substance in atmospheric circulation. Meteor. Monogr., 10, No. 32, 84pp.

Klemp, J.B., and D.K. Lilly, 1978: Numerical simulation of hydrostatic mountain waves. J. Atmos. Sci., 35, 78-107.

, and R.B. Wilhelmson, 1978: The simulation of three-dimensional convective storm dynamics. $J$. Atmos. Sci., 35, 1070-1096.

Matsumoto, S., K. Ninomiya, K. and S. Yoshizumi, 1971: Characteristic features of Baiu front associated with heavy rainfall. J. Meteor. Soc. Japan, 49, 267-281.

Nakajima, K. and T. Matsuno, 1988: Numerical experiments concerning the origin of cloud clusters in the tropical atmosphere. To be published.

Ninomiya, K. and T. Akiyama, 1972: Medium-scale echo clusters in the Baiu front as revealed by multi-radar composite echo map. Part I. J. Meteor. Soc. Japan, 50, 558-569.

, and K. Yamazaki, 1979: Heavy rainfalls associated with frontal depression in Asian subtropical humid region (II). J. Meteor. Soc. Japan, 57, 399-413.

- M. Ikawa and T. Akiyama, 1981: Long-lived medium-scale cumulonimbus cluster in Asian subtropical humid region. J. Meteor. Soc. Japan, 59, 564-577.

Ogura, Y., T. Asai and K. Dohi, 1985: A case study of a heavy precipitation event along the Baiu front in northern Kyushu, 23 July 1982: Nagasaki heavy rainfall. J. Meteor. Soc. Japan, 63, 883-900.

Orlanski, I, 1976: A simple boundary condition for unbounded hyperbolic flows. J. Comput. Phys., 21, 251-269.

Saitoh, S., and H. Tanaka, 1987: Numerical experiments of conditional symmetric baroclinic instability as a possible cause for frontal rainband formation. Part $\mathrm{I}$. A basic experiment. J. Meteor. Soc. Japan, 65, 675-708.

Seltzer, M.A., R.E. Passarelli and K.A. Emanuel, 1985: The possible role of symmetric instability in the formation of precipitation bands. J. Atmos. Sci., 42, 2207-2219.

Stone, P.H., 1966: On non-geostrophic baroclinic stability. J. Atmos. Sci., 29, 419-426.

Wolfsberg, D.G., K.A. Emanuel and R.E. Passarelli, 1986: Band formation in a New England winter storm. Mon. Wea. Rev., 114, 1552-1569.

Yoshizumi, S., 1977: On the structure of intermediatescale disturbances on the Baiu front. J. Meteor. Soc. Japan, 55, 107-120. 


\title{
前線付近に発生する帯状降雨域の形成メカニズムとしての 条件付対称傾圧不安定の数值実験 \\ 第 II 部 水蒸気補給の効果
}

\author{
斎藤定・田中浩 \\ （名古屋大学水圈科学研究所）
}

条件付対称傾JE不安定 (Conditional Symmetric Baroclinic Instability, CSBI) の循環は下層への水蒸 気の補給によっていかに変化して行くのか。また CSBI の循環はどのように対流セルを誘起し更にそれ をコントロールするのであろらか。これらの問題について数值実験により挆ることが本論文の目的であ る。用いた数值モデルは下層に水蒸気の補給を行っている点を除けば、第I部で使用したものと同一で ある。水蒸気補給がないケース、水蒸気補給率が小さいケース拈よび水蒸気補給率が大きいケースの 3 種類のケースの実験を行った。これら３つのケースにつき雲、降水および成層の変化に着目した。

水蒸父補給率が適度である場合は、補給なしの場合と同様に傾斜した構造を持つ雲が CSBI の循環に よって形成された。この場俞、いくつかの雲水量のノード（節）が傾斜した玨の中に現れた。このノー ドは傾斜した隹の内部での対流セルにより形成されたものである。このノードに対応して幅が広く降雨 強度の小さい降雨域の中に、幅が狭く強い降雨強度を持つ降雨域が現れた。中部対流圈の刘流不安定層 内に generating cell もみられた。水蒸父補給率が大きい場合には CSBI の循環の収束域および傾斜した 対流不安定層内で対流雲が急速に成脣した。緯度方向の降雨域の幅は狭くなったが降雨強度は著しく増 大しだ。

帯状降雨域の形成に扔いて CSBI の循環が果たす最も重要な効果の一つは傾斜した対流不安定層を誘 起することである。この CSBIの循環により形成される対流不安是は水蒸気の補給率が增加するのに 伴って著しく促進される。水蒸気の補給率が大きい逿合、下層に形成される対流不安定が CSBI の循環 の収束域でトリガーされ、そこでの対流活動が活発化する。 